\title{
PENGARUH RESTRAIN PADA PASIEN PERILAKU KEKERASAN TERHADAP PENURUNAN PERILAKU KEKERASAN DI RUANG IGD RSJD ATMA HUSADA MAHAKAM SAMARINDA
}

\author{
St Nurrahmatiyah" ${ }^{1)}$, Edi Sukamto'), Gajali Rahman ${ }^{1)}$ \\ ${ }^{1)}$ Poltekkes Kemenkes Kalimantan Timur \\ E-mail: tiyah53@yahoo.com
}

\begin{abstract}
Background: According to WHO data in 2012 the number of people with mental disorders worrying globally, about 450 million people suffering from mental disorders. People with mental disorders a third live in developing countries, as many as 8 out of 10 people with mental disorders that do not get treatment.

Objective: To identify the effect of restrain on patient violent behavior toward decreasing violent behavior in room of ER Hospital Atma Husada Mahakam Samarinda.

Design: The type of research used in this study is quasi experiment. Quasi experimental research is a study that tested an intervention in a group of subjects with or without a comparison group.

Results: showing the characteristics of respondents mostly male sex numbered 14 people (70\%) and women as many as 6 people $(30 \%)$. And shows the characteristics of respondents by age less than 25 years as many as 6 people $(30 \%), 26-40$ years as many as 13 people $(65 \%)$, and more $\geq 45$ years as many as 1 person $(5 \%)$. Test results Wilcoxon Test performed obtained value $\mathrm{P}=0.001(\mathrm{P}<0.05)$

Conclusion: There is influence of Restrain on the decrease of violent behavior in patient of violent behavior residing in room of IGD RSJD Atma Husada Mahakam Samarinda.
\end{abstract}

Keywords: Restrain, violent behavior

\begin{abstract}
ABSTRAK
Pendahuluan : Menurut data WHO pada tahun 2012 angka penderita gangguan jiwa mengkhawatirkan secara global, sekitar 450 juta orang yang menderita gangguan mental. Orang yang mengalami gangguan jiwa sepertiganya tinggal di negara berkembang, sebanyak 8 dari 10 penderita gangguan mental itu tidak mendapatkan perawatan.

Tujuan : untuk Mengidentifikasi pengaruh restrain pada pasien perilaku kekerasan terhadap penurunan perilaku kekerasan di ruang Igd Rumah Sakit Atma Husada Mahakam Samarinda.

Desain : Jenis penelitian yang digunakan dalam penelitian ini adalah quasi experiment. Penelitian quasi experiment adalah penelitian yang menguji coba suatu intervensi pada kelompok subyek dengan atau tanpa kelompok pembanding.

Hasil : menunjukkan karakteristik responden sebagian besar berjenis kelamin laki-laki berjumlah 14 orang $(70 \%)$ dan perempuan sebanyak 6 orang $(30 \%)$. Dan menunjukkan karakteristik responden menurut umur kurang dari 25 tahun sebanyak 6 orang (30\%), 26-40 tahun sebanyak 13 orang $(65 \%)$, dan lebih $\geq$ 45 tahun sebanyak 1 orang $(5 \%)$. Hasi uji Wilcoxon Test yang dilakukan diperoleh nilai $\mathrm{P}=0,001$ $(\mathrm{P}<0,05)$

Kesimpulan : Ada pengaruh Restrain terhadap penurunan perilaku kekerasan pada pasien perilaku kekerasan yang berada di ruang Igd RSJD Atma Husada Mahakam Samarinda.
\end{abstract}

Kata kunci : Restrain, perilaku kekerasan 


\section{PENDAHULUAN}

Menurut Undang-undang Republik Indonesia nomor 18 tahun 2014 Tentang Kesehatan jiwa, ODGJ atau orang dengan gangguan jiwa adalah orang yang mengalami gangguan dalam pikiran, perilaku, dan perasaan yang termanifestasi dalam bentuk sekumpulan gejala atau perubahan perilaku yang bermakna, serta dapat menimbulkan penderitaan dan hambatan dalam menjalankan fungsi sebagai manusia.

Menurut World Health Organization (WHO), Kesehatan jiwa merupakan suatu keadaan dimana seseorang yang terbebas dari gangguan jiwa, dan memiliki sikap positif untuk menggambarkan tentang kedewasaan serta kepribadiannya. Menurut data WHO pada tahun 2012 angka penderita gangguan jiwa mengkhawatirkan secara global, sekitar 450 juta orang yang menderita gangguan mental. Orang yang mengalami gangguan jiwa sepertiganya tinggal di negara berkembang, sebanyak 8 dari 10 penderita gangguan mental itu tidak mendapatkan perawatan (Paritas, Derajat, Perineum, \& Sari, 2012).

Berdasarkan study pendahuluan yang telah dilakukan didapatkan data, bahwa pasien yang masuk di RSJD Atma Husada Mahakam Samarinda yaitu pasien perilaku kekerasan. Pasien biasanya dibawa oleh keluarga maupun dibawa oleh dinas sosial setempat, pasien dibawa untuk mendapatkan penanganan yang tepat. Berdasarkan hasil wawancara pada perawat di ruang IGD yang telah dilakukan didapatkan data angka kejadian pasien perilaku kekerasan di ruang IGD RSJD Atma Husada Mahakam Samarinda Pada bulan Januari-Desember tahun 2016 terdapat 408 kasus pasien perilaku kekerasan. Untuk penanganan awal pasien ketika masuk pasien diberikan tindakan restrain atau fiksasi, setelah direstrain pasien diberikan terapi farmakologi sesuai instruksi dokter. Kemudian pasien dilakukan observasi pengikatan per 15 menit dan observasi tanda-tanda vital. Dari data tersebut menggambarkan bahwa pasien perilaku kekerasan harus segera ditangani apabila tidak ditangani dapat membahayakan diri pasien, orang lain maupun lingkungan sekitarnya.

Berdasarkan uraian latar belakang maka rumusan masalah dalam penelitian ini adalah '"apakah ada 
pengaruh restrain pada pasien perilaku kekerasan terhadap penurunan perilaku kekerasan di ruang Igd RSJD Atma Husada Mahakam Samarinda”.

\section{METODE PENELITIAN}

Jenis penelitian yang digunakan dalam penelitian ini adalah quasi experiment. Penelitian quasi experiment adalah penelitian yang menguji coba suatu intervensi pada kelompok subyek dengan atau tanpa kelompok pembanding. Namun, tidak dilakukan randomisasi untuk memasukkan subyek ke dalam kelompok perlakuan atau control (Dharma.K.K, 2011)

\section{Rancangan penelitian yang} digunakan adalah pre and post test without control, pada desain ini peneliti hanya melakukan intervensi pada satu kelompok tanpa pembanding.

Tekhnik pengumpulan data dari tahap persiapan antara lain mengurus surat izin pendahuluan dan izin penelitian ke kantor Program Studi D-IV Keperawatan Politeknik Kesehatan Kementerian Kesehatan Kalimantan Timur. Kemudian melakukan studi pendahuluan di ruang IGD RSJD Atma Husada Mahakam Samarinda, Metode pengumpulan data penelitian ini diperoleh dari data primer melalui observasi langsung terhadap penurunan perilaku kekerasan sebelum dan sesudah dilakukan restrain dengan menggunakan lembar observasi.

\section{HASIL DAN PEMBAHASAN}

1. Karakteristik Responden Menurut Jenis Kelamin dan umur pada pasien perilaku kekerasan di ruang IGD Atma Husada Mahakam Samarinda

\begin{tabular}{lll}
\hline Karakteristik & Frekuensi & \multicolumn{1}{c}{$\%$} \\
\hline Jenis Kelamin & & \\
Laki-laki & 14 & 70 \\
Perempuan & 6 & 30 \\
Total & 20 & 100 \\
Umur & & \\
$\leq 25$ tahun & 6 & 30 \\
$26-44$ tahun & 13 & 65 \\
$\geq 45$ tahun & 1 & 5 \\
Total & 20 & 100 \\
\hline
\end{tabular}

2. Hasil uji normalitas penurunan perilaku kekerasan pada responden yang diberikan tindakan Restrain

\begin{tabular}{lc}
\hline \multicolumn{1}{c}{ Perilaku } & $\begin{array}{c}\text { Shaphiro Wilk } \\
\text { Test }\end{array}$ \\
\hline \multicolumn{1}{c}{$\begin{array}{l}\text { Perilaku kekerasan } \\
\text { sebelum Restrain }\end{array}$} & 0,001 \\
$\begin{array}{l}\text { Perilaku } \\
\text { kekerasan setelah }\end{array}$ & 0,02 \\
Restrain & \\
Selisih & 0,019 \\
\hline
\end{tabular}


3. Hasil analisis Wilcoxon Test penurunan perilaku kekerasan pada pasien perilaku kekerasan dengan intervensi restrain di ruang IGD

RSJD Atma Husada Mahakam

Samarinda

\begin{tabular}{|c|c|c|c|c|}
\hline $\begin{array}{l}\text { Perilaku } \\
\text { kekerasan }\end{array}$ & $\begin{array}{l}\text { Med } \\
\text { ian }\end{array}$ & $\begin{array}{l}\text { Maksi } \\
\text { mum }\end{array}$ & $\begin{array}{l}\text { Mini } \\
\text { mum }\end{array}$ & $\mathrm{P}$ \\
\hline $\begin{array}{l}\text { Sebelum } \\
\text { intervensi }\end{array}$ & 24 & 24 & 22 & 0,001 \\
\hline $\begin{array}{l}\text { Setelah } \\
\text { intervensi }\end{array}$ & 20 & 21 & 17 & \\
\hline Selisih & 4 & 3 & 5 & \\
\hline
\end{tabular}

Berdasarkan tabel diatas menunjukkan karakteristik responden sebagian besar berjenis kelamin laki-laki berjumlah 14 orang (70\%) dan perempuan sebanyak 6 orang $(30 \%)$. karakteristik responden menurut umur kurang dari 25 tahun sebanyak 6 orang (30\%), 26-40 tahun sebanyak 13 orang $(65 \%)$, dan lebih $\geq 45$ tahun sebanyak 1 orang $(5 \%)$. Hal ini sejalan dengan penelitian yang dilakukan oleh Waode siti hartini pada tahun 2014, jenis kelamin laki_laki merupakan salah satu variabel diskriptif yang dapat memberikan perbedaan angka kejadian pada pria dan wanita Pada berbagai penyakit tertentu, rasio jenis kelamin harus selalu diperhitungkan karena bila suatu penyakit lebih tinggi frekuensinya pada pria di banding wanita. Selain itu pula harus diperhitungkan adanya ekspresi maupun keluhan keluhan penyakit tertentu. Menurut perbedaan jenis kelamin, jenis kelamin laki-laki mempunyai tanggung jawab lebih besar dibandingkan perempuan, sehingga kaum laki-laki tingkat stressnya lebih tinggi. Bila usaha seseorang untuk mencapai suatu tujuan mengalami hambatan maka akan timbul dorongan agresif yang pada gilirannya akan memotivasi perilaku yang untuk melukai orang atau objek yang menyebabkan frustasi.

Berdasarkan hasil penelitian dan teori sebelumnya bahwa umur produktif dapat mempengaruhi seseorang mengalami gangguan jiwa perilaku kekerasan apabila seseorang tidak dapat memenuhi keinginannya. Hal ini dihubungkan dengan teori menurut WHO atau World Health Organization bahwa usia rentang 18-45 tahun merupakan usia produktif dimana seseorang merasa sudah matang secara fisik dan biologis. Pada usia inilah aktifitas fisik sering menimbulkan stress yang merupakan penyakit yang sering menghinggapi masyarakat. Pada usia tersebut termasuk usia produktif sehingga pada umumnya pada usia tersebut seseorang ingin beraktualisasi secara maksimal, 
sehingga segala sesuatu bila tidak terwujud akan timbul rasa kekecewaan dan bila mekanisme koping seseorang tidak efektif potensial terjadi gangguan jiwa, salah satunya perilaku kekerasan. Hal ini, salah satunya terjadinya gangguan jiwa perilaku kekerasan (Keliat, 2003).

Hasil uji normalitas Shapiro-Wilk test perilaku kekerasan sebelum dan sesudah intervensi restrain didapatkan variabel perilaku kekerasan sebelum dan sesudah dilakukan intervensi restrain data tidak berdistribusi normal. Hal tersebut dilihat dari nilai sig. sebelum $0,001<0,05$ dan nilai sig. setelah 0,02 sehingga uji analisa data yang digunakan adalah uji Wilcoxon test dengan melihat nilai median, nilai minimum dan nilai maximum.

Dari hasil uji Wilcoxon Test didapatkan nilai minimum setelah intervensi lebih kecil dari nilai minimum $17<22$ dengan selisih minimum 5 demikian juga dengan nilai maksimum dan median. Nilai maksimum setelah intervensi lebih kecil dibanding nilai minimum $21<24$ dengan selisih 3 begitupun dengan nilai median yaitu nilai median setelah intervensi lebih kecil dari nilai median sebelum intervensi yaitu $20<24$ dengan selisih 4 .
Berdasarkan tabel didapatkan nilai maximum, minimum dan median mengalami perubahan yaitu mengalami penurunan setelah diberikan intervensi restrain. Hal ini sejalan dengan penelitian yang dilakukan oleh Dwi ariani Sulistyowati, E Prihatin bahwa penggunaan restrain dapat menurunkan perilaku kekerasan dikarenakan dengan adanya pembatasan gerak sehingga dapat mengontrol emosi yang mempengaruhi proses fikir serta ketegangan otot.

Perilaku kekerasan merupakan suatu bentuk perilaku agresi atau kekerasan yang ditunjukkan baik secara verbal, fisik, ataupun keduanya kepada suatu objek, orang atau diri sendiri, yang mengarah pada potensial untuk destruktif atau secara aktif menyebabkan kesakitan, bahaya, dan penderitaan (Wahyuningsih, Keliat, \& Hastono, 2011). Perilaku kekerasan yang dimaksud meliputi respon fisik, verbal, dan motorik pasien. Penatalaksanaan penanganan perilaku kekerasan sangat diperlukan salah satu penanganan yang dapat dilakukan dengan cara restrain.

Sejalan dengan penelitian Kandar prabawati setya pambudi pada tahun 2013 prosedur restrain yang telah 
dilakukan di RSJD Dr. Amino Gondohutomo Semarang telah sesuai dengan SOP yang telah ditetapkan oleh rumah sakit dan tidak memberikan efek samping. Pasien di fiksasi selama 4 jam serta tidak mengalami kekambuhan. Sehingga dari penelitian sebelumnya restrain dalam psikiatrik, secara umum dapat diberikan untuk pasien perilaku kekerasan guna membatasi gerakan ekstremitas pasien. Hal ini menurut buku Iyus Yosep menjelaskan tujuan dari restrain manual terhadap pergerakan klien. Dengan Indikasi pengekangan :

a. Perilaku amuk yang membahayakan diri sendiri atau orang lain.

b. Perilaku agitasi yang tidak dapat dikendalikan dengan pengobatan

c. Ancaman terhadap integritas fisik yang berhubungan dengan penolakan klien untuk beristirahat, makan, dan minum

d. Permintaan klien untuk pengendalian perilaku eksternal pastikan tindakan ini telah dikaji dan berindikasi terapeutik.

\section{KESIMPULAN}

1. Karakteristik responden perilaku kekerasan yang diberikan tindakan restrain didominasi oleh jenis kelamin laki-laki dengan usia 26 -
44 tahun dimana usia ini adalah usia produktif.

2. Terdapat perbedaan penurunan perilaku kekerasan sebelum dan sesudah diberikan tindakan restrain, yaitu terdapat penurunan perilaku kekerasan setelah diberikan intervensi restrain dibanding sebelum diberikan restrain.

3. Restrain berpengaruh terhadap penurunan perilaku kekerasan pada pasien perilaku kekerasan yang berada di ruang IGD RSJD Atma Husada Mahakam Samarinda. Hal ini dapat di lihat dari analisa uji Wilcoxon Test yaitu nilai $\mathrm{P}=0,001$ $(\mathrm{P}<0,05)$ artinya "Ha diterima" ada pengaruh restrain pada pasien perilaku kekerasan terhadap penurunan perilaku kekerasan di ruang Igd RSJD Atma Husada Mahakam Samarinda.

\section{UCAPAN TERIMA KASIH}

Penulis menyadari bahwa dalam proses penyusunan skripsi ini dapat diselesaikan karena adanya dukungan dari berbagai pihak. Pada kesempatan ini penulis menyampaikan ucapan terima kasih yang tak terhingga serta kepada Allah Subhanahu wa ta'aalaa, yang telah memberikan rahmat dan kasih 
sayang yang tiada terhingga, Bapak

Drs. H. Lamri, M. Kes selaku

Direktur Politeknik Kesehatan

Kementerian Kesehatan Kalimantan

Timur, Bapak Ismansyah, S. Kp, M.

Kep selaku Ketua Jurusan

Keperawatan, Bapak Ns. Parellangi,

S. Kep, M. Kep, M. HKes selaku

Ketua Program Studi D-IV

Keperawatan, Direktur Rumah Sakit

Jiwa Atma Husada Mahakam

Samarinda, Edi Sukamto, S.Kp.,M.

Kep sebagai pembimbing 1 yang telah banyak membantu dalam penyusunan Skripsi ini. Ns. Gajali Rahman , M. Kep sebagai pembimbing 2 yang telah banyak membantu dalam penyusunan Skripsi ini.

Dan kedua orangtua yang telah memberikan dukungan moril maupun materil beserta teman-teman yang telah mendukung dalam penyusunan skripsi penelitian dan semua pihak yang telah membantu dalam penyusunan proposal ini yang tidak dapat disebutkan satu per satu.

\section{DAFTAR PUSTAKA}

Akemat, K. (2010). Model Praktik Keperawatan Profesional jiwa. jakarta : EGC.

Dahlan. S. (2008). statistik untuk kedokteran dan kesehatan. jakarta : salemba medika.

Dharma.K.K. (2011). metodologi penelitian keperawatan. Jakarta.

Hartono, kusuma wati. (2011). Buku Ajar Keperawatan Jiwa. jakarta: EGC.

Keliat. (2002). Proses Keperawatan Kesehatan Jiwa. 2002.

Laraia, S. (2015). principles and practice of psichiatric Nursing. Medical University of South Carolina.

Paritas, H., Derajat, D., Perineum, R., \& Sari, N. P. (2012). Pengaruh Pendidikan Kesehatan Tentang Resiko Perilaku Kekerasan ( RPK) Terhadap Pengetahuan Keluarga Dalam Merawat Pasien Di Poli Jiwa RSJD Dr. RM . Soedjarwadi. Jawa tengah.

Purwanto, R. S. \&. (2009). asuhan keperawatan jiwa. Yogyakarta: Graha.

Stuart, D. (2006). Buku Saku Keperawatan Jiwa. Jakarta.

Sugiyono. (2010). metode penelitian kuantitatif kualitatif dan RND. Bandung.

Sulistyowati, D. ariani, \& Prihantini, E. (2014). Keefektifan penggunaan restrain terhadap penurunan perilaku kekerasan pada skizofrenia. Jurnal Terpadu Ilmu Kesehatan, 3(2), 138-143.

Videbeck. (2008). buku ajar keperawatan jiwa. jakarta: EGC.

Wahyuningsih, D., Keliat, B. A., \& Hastono, S. P. (2011). Penurunan perilaku kekerasan pada klien skizofrenia dengan Assertiveness Training (AT). Jurnal Keperawatan Indonesia, 14(1), 51-56. Retrieved from http://www.depkes.go.id/article/vie w/201410270011/stop-stigma-dandiskriminasi-terhadap-orang-denga n-gangguan-jiwa-odgj.html

Yosep, Iyus, S.kp, M. S. (2009). 
Mahakam Nursing Journal Vol 2, No. 3, Mei 2018 : 134-140

Keperawatan Jiwa,Edisi Revisi.

Bandung.

Yosep, I. (2007). keperawatan jiwa (cetakan 1). Bandung. 